\title{
The relationship between microwear on human teeth and nutrition: Samples from ancient Anatolian societies
}

\author{
Serpil Özdemir ${ }^{1^{*}}$, Alper Yener Yavuz $^{1^{*}}$, Ayla Sevim Erol ${ }^{2}$ \\ ${ }^{1}$ Department of Anthropology, Faculty of Arts and Sciences, Mehmet Akif Ersoy University, Burdur, Turkey; \\ *Corresponding Author: serpilozdemir@mehmetakif.edu.tr, alpyeneryavuz@mehmetakif.edu.tr \\ ${ }^{2}$ Department of Anthropology, Faculty of Letters, Ankara University, Ankara, Turkey
}

Received 22 January 2013; revised 24 February 2013; accepted 9 March 2013

Copyright (C) 2013 Serpil Özdemir et al. This is an open access article distributed under the Creative Commons Attribution License, which permits unrestricted use, distribution, and reproduction in any medium, provided the original work is properly cited.

\section{ABSTRACT}

The relationship between tooth of living species and nutrition is so important for anthropologic researches that, it is among the most considered issues in almost all the researches that have been made about these topics. Tooth, as being one of the most significant materials that give information about diet, environmental relationships and cultural structure, has been a constant research topic. It has been proved with the researches that, the food stuffs, which living species consumed, have a fundamental role on tooth wear. The recently recognized micro marks on occlusal are also evaluated carefully as well as the macro wears, which are defined as the apparent wears on tooth enamel. These micro marks have several characteristics about the ingredients, hardness, size and chewing force of the nutrients. In this regard, the tooth samples of Agora of Smyrna, Kyzikos, Minnetpınarı and Güllüdere skeletons that lived in Anatolia-also constituted the sample of this research-have been investigated and the diet of these societies has been examined depending upon the micro marks on the teeth of these societies' people. Firstly, the diet of these societies has been investigated by examining micro tooth wears. Then, the relationship of these societies has been studied. By examining micro tooth wears of these societies, it has been discussed that whether the factors of age, sex, and facet are effective or not on micro wear marks. As a result of this study, it has been observed that societies that lived in different areas have different diets; and micro marks on teeth are significant indi- cators of living spaces, subsistence economies and life styles of the societies.

Keywords: Microwear; Macrowear; Facet; Age; Sex

\section{INTRODUCTION}

The investigation of human skeletons gathered from archeological and anthropological excavations is of capital importance for the enlightenment of human history. Every piece of human skeleton is an important data source in this process. Teeth, the most durable pieces of the body against all factors, can be protected without deterioration and found intensively in excavations. Therefore, teeth constitute most of these data sources.

Teeth are exposed to some pathological lesions because of the factors that cause infections in mouth during and after the nutrition. By making use of these lesions; the mouth and dental health, life styles and environmental relationships of humans are evaluated. Tooth wears are also among the significant data source that can give information about the diet, life styles and occupations of Ancient people. Some important scientific studies are added to the anthropological studies which were initially held on macroscopic level by means of emerging techniques and detailed analyses. Dental micro wear studies are also one of these analyses which examine the wears occurred on tooth enamel under the microscope. With the development of Scanning Electron Microscope (SEM) used in these studies, both tooth samples and examined replica materials have been scanned comprehensively. Thus, these developments added a new dimension to micro wear studies. There are some studies held on both alive and fossil samples related to this topic. In these studies, it has been proved that there is a relationship between the hardness and dimensions of the supplies con- 
sumed by these societies and the dental micro marks [16]. However, there should be studies about more societies that lived in different periods in order to make the societies gain a historical size within a chronological frame.

There are few studies about the micro wears on the teeth of Ancient Anatolian societies in our country. One of these few studies is held by Boz (2006). In her study of Çatalhöyük, Aşıklıhöyük, Olumluhöyük and Ikiztepe societies that are dated back Neolithic and Bronze Age, these four societies are compared among themselves [1].

\section{MATERIAL \& METHOD}

Within the concept of study, the micro wears on the teeth of Minnetpınarı, Güllüdere, Kyzikos and Agora of Smyrna people are examined and acquired data are evaluated with the archeological and anthropological findings of the related society (Figure 1). By examining the micro tooth wears of the related society, it is aimed to:

- Identify the feeding habits and food preparation techniques of these societies;

- Present the distinctive social characteristics of each society by evaluating the Güllüdere and Minnetpınarı societies of the East Anatolian Ancient Period, and Agora of Smyrna and Kyzikos societies of the West Anatolian Ancient Period respectively;

- Examine whether there is a major difference between these regions by considering the distinctive social characteristics of each society and comparing them as east and west societies;

- Identify whether the age, sex and facet factors of individuals affect the micro wear marks, and whether these marks vary according to the sexes.

The material of this study is constituted of totally 100 pieces of mandibular M1 and M2; 18 from Izmir/Agora of Smyrna dated Byzantine Period [7], 11 from Balıkesir/ Kyzikos dated 2nd Century AD, 37 from Erzurum/Güllüdere dated Middle Age [8], and 34 from Kahramanmaraş/Minnetpınarı dated Middle Age [9] (Image 1). Anthropological analyses of these societies chosen for this study are made at Anthropology Laboratories of Ankara

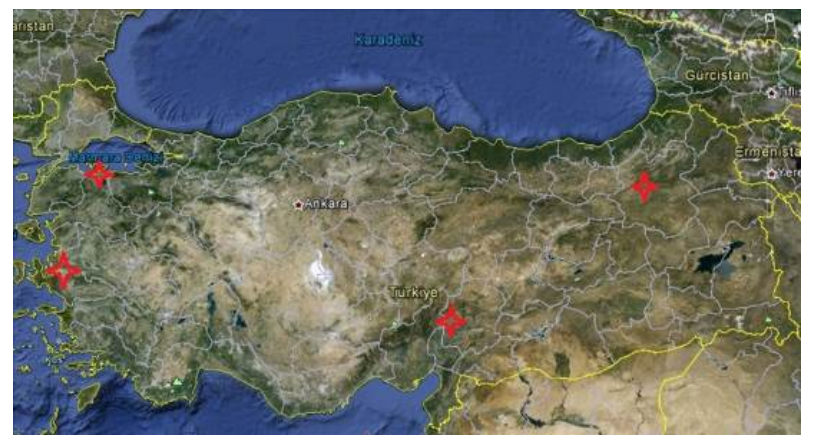

Figure 1. The location of sites on map of Turkey.
University, Faculty of Languages, History and Geography [10-13], and SEM analyses of the micro wear marks on the teeth chosen from these skeletons are made in cooperation with Scientific and Technological Research Laboratories Committee of Kırıkkale University. During these analyses, first, teeth are veneered with gold in Polaron Sputter Coater device. Then, aforementioned marks are shot on JSM $560030 \mathrm{kv}$ SEM that are available at Electron Microscope Laboratories.

In order to make out whether feeding habits vary on sexes, each of the societies, which constitute the sample of this study, are examined by classifying them as female and male individuals, and the ones whose sex could not be identified [10-13]. When it is considered that tooth wears increase in direct proportion to age, the sample is compared by classifying the age groups within the range of adults above the age of 15 and children aged 15 and below to determine the relationship between feeding habits and age.

Original teeth are used due to the low pressure of the microscope used in this study and the long process of replica preparation, and also not to damage the material. Protective chemicals used in field survey to preserve the stability of the teeth and accumulations such as dust and mud make the microscopic view blur; thus this may cause data loss. Therefore, teeth, forming our sample, are cleaned by using a method that is proved to be harmless, and made ready for SEM.

In this study, crush and chop facet "ct" and digest facets " $f 9$ ", "fx", and "10n" are examined in order to see the effects of two different functions such as crush-chop and digest on micro wear marks. The regulated form of facet numbering system constituted by Kay and Hiiemae (1974) is used in our study $[2,14]$.

Before the examinations on Scanning Electron Microscope, photos of the occlusal from all the examined teeth are taken by using light microscope and 10 times magnifying so as to have a clear view of the occlusal facets (Figure 2).

After the photography of the facets on occlusal, at first step, photos are suited to micro wear program for measurement. For this purpose, photos are minimized on resolution of 200 and $640 \times 480$ pixels to make them suit to the micro wear program formed by Ungar [15]. All the photos taken on Scanning Electron Microscope are made ready for measurement after this process. Microwear 4.02 version of the program, which is formed by P. Ungar to measure the micro wear marks, is used.

In micro wear studies, marks on tooth enamel are classified as scratch and pit by using the width and length proportions. Different researchers used different proportions such as 2:1, 4:1, or 10:1 in this classification. In our study, the proportion of $4: 1$, which is suggested by Grine, is used [14,16-19]. All the figures, whose width and length 


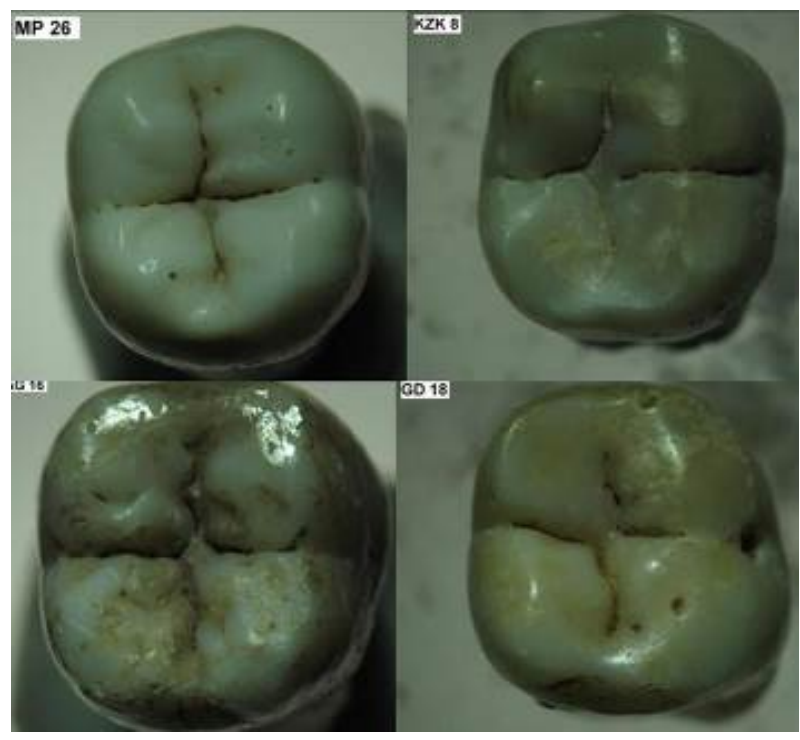

Figure 2. Photography of teeth on light microscope.

proportions are greater than 4:1 proportion, are regarded as scratch; and the ones, whose width and length proportions are less than or equal to $4: 1$ proportion, are regarded as pit [20,21].

After the measurements are completed, some evaluations are carried out about diets by using the variables such as number of pits, number of scratches, number of total figures, pit width, pit length, pit percent and scratch width as they are all significant components for information.

After the measurement of all the photos is completed, data are transferred to statistics program of SPSS 20.0, according to their archeological excavation sites. Each tooth, facet and sex, which is evaluated for four Anatolian societies, is classified respectively; number of measured individuals for each facet is determined, and then facets are sorted according to their sexes.

\section{RESULTS}

In micro wear studies carried out on teeth, it is quite apparent that the number and size of these micro wears are relevant with the amount and hardness of the consumed food $[1,5,22,23]$. It is proved that scratch and pit extents on teeth give concrete information about the diet of individual. It is also determined that there are more scratches in groups which consume softer foods while there are more and greater pits in groups which consume harder foods [1,24-26].

It is proved that the pit shaped micro wear marks seen on teeth are generally formed as a result of abrasion (the contact of teeth with foods) and hard substances which require more chewing [20,25,27]. There found more pit percent on teeth of carnivores which feed with hard foods and consume small vertebrates and gastropods in com- parison with the teeth of carnivores which feed soft foods and consume caterpillars or fleshy parts of vertebrates [27]. In addition, there found high level of pits and less scratch on teeth of the routinely bone consumers such as hyena [28]. As for the scratch shaped micro wear marks seen on teeth; it is determined that they are largely formed as a result of atrision and consumption of softer foods. The truth that the formation of these marks is caused by fitolits or dust and dirt particles is accepted by most researchers $[29,30]$.

When the numbers of pits and scratches in our sample are examined, it is seen that the minimum pit is in Kyzikos society, the least number of pits is in Agora (380), and then Minnetpınarı and Güllüdere follow consecutively. Likewise, it is determined that the least number of scratches is seen in Kyzikos, and Agora, Minnetpinarı and Güllüdere follow consecutively (Figure 3).

Within the concept of this study, it is also investigated whether the feeding habits vary on the micro wear marks between female and male. As a consequence of the comparisons, on the teeth of Agora people, criterions of total form number in fx facet $(p=0.015)$ (Image 3 ) and scratch width in ct facet $(p=0.049)$ differ statistically between female-male. It is observed that the scratches on the tooth of male in ct facet are wider, and on the other hand, total form number is more for female than male in fx facet, which also means there are denser micro wear marks for female. Except these two facets of Agora (fx and ct) and their criterions, there found no differences between female and male teeth (Figure 4).

As for Kyzikos, another western society, for 10n facet, it is seen that the scratches on teeth of male are wider than the group of which sex we cannot define certainly. For fx facet, it is also seen that the width of pits is lesser in male individual; in other words, the pits are smaller in male individual. When the eastern societies are considered, it is obvious that there is difference between two sexes on the teeth of Güllüdere people in $\mathrm{f} 9$ facet, and it is seen, when the SEM photographs of female individuals are examined, that there are more scratches on teeth of female. In Minnetpinarı, it is tested whether there is difference on the micro wear variables among the individuals whose sex could be defined, and the difference between sexes is not regarded notable.

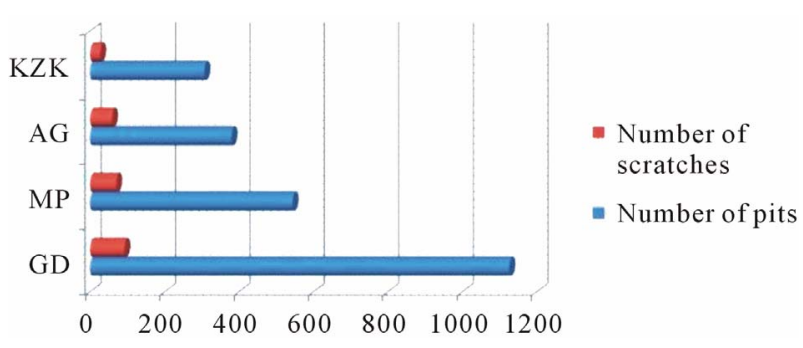

Figure 3. Number of scratches and number of pits. 


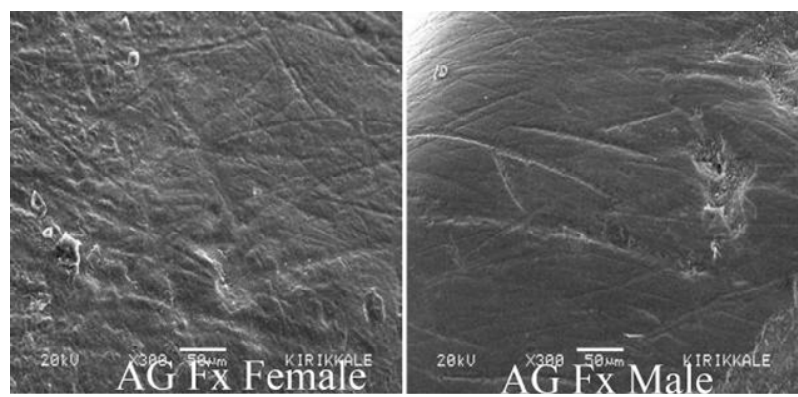

Figure 4. Population of agora facet fx.

In order to understand whether the feeding habits change with regard to age and whether this is reflected on micro wear patterns; societies are divided into two groups as individuals who are below and above the age of 15 , and analyzed by applying the $t$ test. As a result of these analyses;

The difference between two age groups is regarded notable in terms of number of pits $(p=0.048)$ for Agora individuals in 10n facet. When this variable is excluded, there found more values in the age group of above 15; while there is not an apparent difference on other variables in both age groups. For Agora sample, none of the micro wear criterions are regarded significant for these two age groups in ct, $\mathrm{f} 9$ and $\mathrm{fx}$ facets. Although these variables in facets are not notable, they have more values for individuals who are above the age of 15 . Also in Kyzikos society, none of the micro wear criterions are found noteworthy between these two age groups in 10n, ct, f9 and $\mathrm{fx}$ facets.

On the other hand, in $\mathrm{f} 9$ facet of Güllüdere individuals, it is clearly seen that the number of scratches $(p=0.042)$ varies to a great extent between age groups. Apart from this, the difference between age groups is not found significant in any variable of $10 \mathrm{n}$, ct and fx facets. As for the society of Minnettpinarı, the difference between these two age groups is also determined as unimportant in none of the variables of $10 \mathrm{n}, \mathrm{ct}, \mathrm{f} 9$ and $\mathrm{fx}$ facets.

\section{DISCUSSION}

Number of pits is identified more in comparison to the scratches in societies of Güllüdere and Minnetpınarı as they are located in highlands and have an economy dependent on agriculture and livestock; also in societies of Kyzikos and Agora of Smyrna as they are marine societies. As there are mainly pits and fewer scratches in these four Anatolian societies, it is possible that their diet is constituted of hard and larger foods which require more chewing. On the other hand, when the geography, different time zones, different economies are considered, it can be said that foods, which include same amounts or same kinds of abrasives, are not consumed in all sites. In these four sites, which are known to have different feed- ing habits according to the archeological data, it can be also said that the similar characteristics of micro wear marks cannot be explained only with the amount of abrasives or the consumption of the same kind of hard foods. It can be estimated that there may be other factors in the formation of micro wear marks.

Differences of pit sizes indicate the variety of foods that cause these pits. Size and form of pits are proportionate with the size and form of foods and amount of the vertical pressure [28]. When the teeth of the investigated communities are considered, differences on the sizes of the marks are found despite the number of pits is more than the number of scratches. When the pit sizes are examined within the frame of analyses carried out, it is seen that data of Güllüdere and Minnetpınarı, eastern societies, are clustered as they have approximate values. On the other hand, when the data of Kyzikos and Agora of Smyrna, western societies are considered, the pits in Agora of Smyrna are recognized wider while the pits in Kyzikos are narrower.

In this study, it is revealed that the pit sizes of tooth facets are significant criterions that determine the differences among societies. Pits' having been seen in four societies makes the reason of their formations notable. If wider pits indicate the consumption of hard foods, it can be said that Kyzikos people consume soft foods or well processed foods. Nonetheless, if the pit sizes do not give any information about the hardness of foods, then it can be said that these societies consume hard, grainy foods by considering the amount of pit sizes. However, when the archeological data from the sites, where the skeletons of these societies belong to, are taken into consideration, any document displaying their consumption of hard, grainy foods could not be found.

Another micro wear variable that differs among societies is scratch width. It is stated that widths of the scratches are based on the vertical pressure, which is related to the forms of food particles [29-31]. When the scratch widths are compared by considering the regional varieties in archeological sites, Agora society has higher values than Kyzikos society, and Güllüdere society has also higher values than Minnetpınarı society. When these four societies are examined generally, the highest scratch value is seen in Agora society. Teaford and others [4] put forward that the widths of scratches are more both in number and largeness in socities living in seashore when compared to the hinterlands. This condition seems like supporting the result of higher scratch widths in Agora society.

It is determined as a consequence of many researches that environmental factors have strong effects in the formation process of micro wear marks $[1,4,18]$. It is thought that the comparison of Güllüdere and Minnetpınarı, and the comparison of Agora and Kyzikos give truer results 
since they belong to the same periods between each other when the different time zones and different geographies of our samples are considered.

Güllüdere society lived in a natural area which is located in a plain on the north foots of Kizıldağ and $500 \mathrm{~m}$. northwest of Erzurum Aşkale, Güllüdere village. It seems like a proof that they settled there for the stream bed and water sources nearby, agricultural activities and stockbreeding; and constituted sites suitable for such aims [8]. Minnetpınarı society, on the other hand, lived in Minnetpınarı site from Kahramanmaraş province, Andırın town. For these people, it is also stated that they are occupied with stockbreeding because of the geographical location of the district [9]. It is thought that Güllüdere and Minnetpınar1 societies mostly consumed meat based on their means of existence. Also, there found a tandoor (oven) located in a round shaped stone range on the east side of the C-22 trench, in Güllüdere [8]. It is possible that these people might have used this oven in the preparation process of meat as food, and the density of the wears might be the result of outer abrasives and bones which are not severed from meat. In another study carried out by Organ and others, teeth of Native Americans are examined and a large number of middle-sized pits are found on occlusal. It is stated that these marks are caused by the meat which is found in the diet of natives, hard to chew, not fine and clean [32]. There are also documents regarding the agricultural activities in sites both Güllüdere and Minnetp1nar1 societies lived $[8,9]$. This circumstance makes one think that these people might have eaten all the hard plant roots and tubers naturally without any process.

Supply, preparation, and conservation of the foods may differ according to both cultures of the region and seasons in Anatolia. It is thought that eastern Anatolian societies, Gülüdere and Minnetpınarı, might have consumed fresh fruit, vegetables and roots in summer months, and stored cereals, dried fruit and roots and dried meat in winter months. The consumption of foods as fresh or dried according to the seasons and the fitolit rates of these foods seem to be effective in formation of micro wear marks. Therefore, it is possible to say that there is meat, cereal and dried foods among the food stuffs of both Güllüdere and Minnetpınarı societies.

When Agora of Smyrna and Kyzikos teeth are examined visually and statistically, it is seen that there are micro wears in the form of scratches and pits in both societies; however there found more pits than scratches when these micro marks are examined. When these two societies are compared, both the number and width of the pits are more in Agora society. Among the samples, there found a few micro marks, which points out the consumption of soft and fibrous food consisting relatively a few abrasives; and mostly small pits on teeth of Kyzikos society. Another western region society examined within this study, Agora of Smyrna, lived in an important seaport as they have the opportunity to control the sea and have a sheltered port. Agora is visited by some travelers and researchers at different times due to its magnificence in ancient period, and there carried out some studies [7]. Human variety of this region diversified the means of support, diets and cultures of people. When the micro wears on the teeth of Agora of Smyrna people are examined, and the size of marks are evaluated statistically, it is seen that there are more marks on their teeth due to various diets.

When all these four societies are compared, it is concluded that eastern societies consume mostly meat and cereals including hard particulates, while western societies generally consume refined foods and seafood. Thus, in this study, it is clearly proved that micro wear marks on teeth differentiate in various societies because of the periodical and biological differences.

In this study, it is pointed out that facet use is effective in formation of the micro wear marks. 10n, fx, 99 and ct facets are examined one by one and compared to one another. According to this evaluation, the maximum micro wear value is found in fx facet on the teeth of Agora of Smyrna, and ct, f9 and 10n facets followed this respectively. In Kyzikos society, the maximum value is found in 10n and ct facets, and 19 and fx facets followed them. Facet values in Güllüdere society are found as 10n, f9, fx and ct from maximum to minimum. As for Minnetpinar1 society, the rank is $\mathrm{f9}$, fx, ct and $10 \mathrm{n}$ from maximum to minimum respectively.

When the effect of sex on the formation of micro wear marks on teeth is examined, there did not found a notable difference that shows various diets between sexes. In micro wear studies carried out on human teeth, there are not many topics dealing with sex factor. Schmidt stated in the study, in which the feeding habits of Indiana prehistoric societies are investigated, that sex is not an effective factor on micro wear marks [33]. It is also determined with the studies carried out on hominoids and some primate species that micro figures do not differentiate between sexes $[3,17]$. The truth that sex is not a significant factor on micro wear marks is also reported in the study of four Anatolian societies-Aşıklıhöyük, Ikiztepe, Oylumhöyük and Çatalhöyük-carried out by Boz [1].

When an overall evaluation is carried out: The micro wears on teeth of four Ancient period Anatolian societies, consisted of two middle aged and two modern aged, are evaluated statistically by making the SEM analyses. As a result of this evaluation, the micro wear marks on the teeth of Minnetpınarı and Güllüdere people, who lived in Eastern Anatolia, are denser both numerically and visually than Kyzikos and Agora of Smyrna people. However, this difference is not considered as significant when a 
statistical evaluation is carried out. Consequently, the teeth of Minnetpınarı and Güllüdere people, who are known as medieval societies, have more forms in total than Kyzikos and Agora of Smyrna people, who belong to a later period.

When four facets, consisting of $10 \mathrm{n}$, ct, $\mathrm{f} 9$ and fx facets of the teeth of Minnetpınarı and Güllüdere people, are evaluated generally, there encountered more and larger pits in young individuals. This indicates that there are harder, larger foods that require more chewing press in the diet of the mentioned group. As well as the density of the pits change depending on the effect of more than one factor, some researchers also state that it is directly related to the density of the abrasives in foods $[5,19,23,34]$. Existence of large pits is also related to the large and hard pieces in foods $[5,28]$. The increase in the number of scrathes of the second age group may be the indicator of over consumption of foods which require less chewing press but including small abrasives [29,31,34].

Within the concept of our study, it is seen that the scratches on teeth of male are wider when the micro wear marks on the teeth of Western Anatolian societies, Kyzikos and Agora are examined. On the other hand, in Eastern Anatolian societies (Minnetpınarı and Güllüdere), there seen more scratches on the teeth of female in Güllüdere society while there found no difference on micro wear marks between sexes in Minnetpınarı society. Although there are more scratches on the teeth of female in Güllüdere society, statistically, the difference is not regarded notable. Also it is stated that the age of the individual is a significant factor in the formation process of these micro wear marks, and there is difference between age groups even if it is not notable statistically. In Western Anatolian societies, Kyzikos and Agora, when a general evaluation is carried out in $10 \mathrm{n}$, ct, $\mathrm{f9}$ and fx facets, it is apparent that scratch width has a higher value in individuals who are below the age of 15 and this value decreases comparatively as they grow older. Pit sizes, on the other hand, extend in direct proportion to the older age. These values show that small pieces of foods, which require less pressure and include less abrasives, are consumed in individuals aged 15 and below; and larger pieces of foods, which require more chewing press, are consumed in individuals above the age of 15 .

When the results of this study are compared to the study of Boz [1], it is clearly understood that there seen a general decrease in number on micro wear marks from Neolithic to contemporary age. In other words, this study also supports the truth that softer and refined foods have been consumed gradually as the contemporary age approaches, while the foods, which are indigestible and cause more wears on teeth, were consumed more in the past. However, as there are a few studies in this field, the comparison material of these results is restricted. There- fore, it is not correct to generalize the results of this study to all Ancient period societies. This study has the characteristics of a pilot study as well as suggesting an overall idea. Thus, our study will form a basis and a comparison material for the studies that will be carried out in this field in the future.

\section{ACKNOWLEDGEMENTS}

This project is supported by Mehmet Akif Ersoy University Scientific Research Projects Commission [No: 099-NAP-10]. Thus, we would like to express our sincere thanks firstly to Mehmet Akif Ersoy University Scientific Research Projects Commission, and also to P. Ungar for his notable contibutions and sharings on Microwear program, and to Derya Arslan Yavuz for her scientific contributions.

\section{REFERENCES}

[1] Boz, B. (2006) Dişlerde mikro aşinma tekniğinin beslenme alişkanliklarini belirlemedeki yeri: Eski anadolu toplumlarindan örnekler. Hacettepe Üniversitesi Sosyal Bilimler Enstitüsü Basılmamış Doktora Tezi. doi:10.1002/ajpa.1330590208

[2] Gordon, K. (1980) Dental attrition in the chimpanzee (Pan Troglodytes verus): A scanning electron microscope study. Yayınlanmamış Doktora Tezi, Ann Arbor, 265.

[3] Gordon, K.D. (1982) A study of microwear on chimpanzee molars-Implications for dental microwear analysis. American Journal of Physical Anthropology, 59, 195-215.

[4] Teaford, M.F., Larsen, C.S., Pastor, R.F. and Noble, V. (2001) Pits and scrates microscopic evidence of tooth use and masticatory in La Florida. In: Larsen, C.S., Ed., Bioarchaeology of Spanish Florida: The Impact of Colonialism, University Press of Florida, Gainesville, 82-112.

[5] Grine, F. (1981) Trophic differences between "Gracile" and "Robust" australopithecines: A scanning electron microscope analysis of occlusal events. South African Journal of Science, 77, 203-230.

[6] Maas, M.C. (1991) Enamel structure and microwear: An experimental study of the response of enamel to shearing forces. American Journal of Physical Anthropology, 85, 31-50. doi:10.1002/ajpa.1330850106

[7] Taşlıalan, M. and Drew-Bear, T. (2005) Fouilles de l'agora de smyrne: Rapport sur la campagne de 2004. Anatolia Antiqua, XIII, 371-434.

[8] Şenyurt Y. and İbiş, R. (2005) Așkale ovasinda bir demir çağ ve ortaçağ yerleşmesi güllüdere, bakÜ tiflis ceyhan ham petrol boru hatti projesi arkeolojik kurtarma kazilari proje dökümanlari. Gazi Üniversitesi ARÇED Araştırma Merkezi Yayınları.

[9] Tekinalp, M. (2005) Doğu klikya'da bir orta çağ yerleşkesi minnetpinari. BTC, HPBT Projesi Arkeolojik Kurtarma Kazıları Dökümanları, Ankara, 7.

[10] Sevim, A., Gözlük, P., Durgunlu, Ö., Özdemir, S. and Taşlialan, M. (2005) Symrna agorasi iskeletlerinin paleoantropolojik analizi’. T. C. kültür Bakanlığı Kültür Varlıkları ve Müzeler Genel Müdürlüğü, 21, Arkeometri 
Sonuçları Toplantısı, 125-140.

[11] Kırmızıoğlu Gözlük, P., Yaşar, Z.F. and Yiğit, A. (2009) Kyzikos iskeletlerinin dental analizi. T. C. Kültür Bakanlığı Kültür Varlıkları ve Müzeler Genel Müdürlüğü, 24, Arkeometri Sonuçları Toplantısı, Ankara, 139-149.

[12] Sevim A., Yiğit, A., Gözlük Kırmızıŏlu, P., Özdemir, S. and Durgunlu, Ö. (2007) Erzurum/güllüdere iskeletlerinin paleoantropolojik açidan değerlendirilmesi. T. C. Kültür Bakanlığı Kültür Varlıkları ve Müzeler Genel Müdürlüğü, 22, Arkeometri Sonuçları Toplantısı, 141-160.

[13] Yiğit, A., Sevim, A., Özdemir, S., Durgunlu, Ö. and Gözlük, P. (2008) Kahramanmaraş/minnetpinari iskeletlerinin paleoantropolojik analizi. T. C. Kültür Bakanlığı Kültür Varlıkları ve Müzeler Genel Müdürlüğü, 23, Arkeometri Sonuçları Toplantısı, 91-110.

[14] King, T. (1997) Dental microwear and diet in griphopithecus alpani. Yayınlanmış Doktora Tezi, University College, London, 382.

[15] Ungar, P.S., Brown, C.A., Bergstrom, T.S. and Walker, A. (2003) Quantification of dental microwear by tandem scanning confocal microscopy and scale-Sensitive fractal analysis. The Journal of Scanning Microscopy, 25.

[16] Grine, F. (1986) Dental evidence for dietary differences in australopithecus and paranthropus: A quantitative analysis of permanent molar microwear. Journal of Human Evolution, 15, 783-822. doi:10.1016/S0047-2484(86)80010-0

[17] King, T., Arello, L.C. and Andrews, P. (1999) Dental microwear of griphopithecus alpani. Journal of Human Evolution, 36, 3-31. doi:10.1006/jhev.1998.0258

[18] Teaford, M.F. and Robinson, J.G. (1989) Seasonal or ecological differences in diet and molar microwear in Cebus nigrivittatus. American Journal of Phyiscal Anthropology, 80, 391-401. doi:10.1002/ajpa.1330800312

[19] Teaford, M.F. and Runestad, J.A. (1992) Dental microwear and diet in Venezuelan primates. American Journal of Phyiscal Anthropology, 88, 347-364. doi:10.1002/ajpa.1330880308

[20] Teaford, M.F. (1985) Molar microwear and diet in the genus Cebus. American Journal of Phyiscal Anthropology, 66, 363-370. doi:10.1002/ajpa.1330660403

[21] Teaford, M.F. (1988) A review of dental microwear and diet in modern mammals. Scanning Microscope, 2, 11491175.

[22] Grine, F. and Kay, R.F. (1988) Early hominid diets from quantitative imagine analysis of dental microwear. Nature, 333, 765-768. doi:10.1038/333765a0

[23] Teaford, M.F. and Walker, A. (1984) Quantitative differences in dental microwear between primate species with different diets and a comment on the presumed diet of sivapithecus. American Journal of Phyiscal Anthropology, 64, 191-200 doi:10.1002/ajpa.1330640213

[24] Lewis, P., Gutierrez, M. and Johnson, E. (2000) Ondatra zibethicus dental microwear patterns as a potential tool for paleoenvironmental reconstruction. Journal of Archaeological Science, 27, 789-798.

doi:10.1006/jasc.1999.0502

[25] Ryan, A.S. (1979) Wear stration primate teeth: A scaning electron microscope examination. American Journal of Physical Anthropology, 50, 155-158. doi:10.1002/ajpa.1330500204

[26] Teaford, M.F. (1991) Dental microwear: What can it tell us about diet and dental function? In: Larsen, K.M., Ed., Advences in Dental Anthropology, Alan R. Liss, New York, 341-356.

[27] Strait, S.G. (1993) Molar microwear in extant small-bodied faunivorous mammals: An analysis of feature density and pit frequency. American Journal of Physical Anthropology, 92, 63-79. doi:10.1002/ajpa.1330920106

[28] Valkenburgh, B., Teaford, M.F. and Walker, A. (1990) Molar microwear and diet in large carnivores-Inferences concerning diet in the sabretooth cat, Smiodon fatalis. Journal of Zoology, 222, 319-340. doi:10.1111/j.1469-7998.1990.tb05680.x

[29] Teaford, M.F. and Lytle, J.D. (1996) Diet-induced changes in rates of human tooth microwear: A case study involving stone-ground maize. American Journal of Physical Anthropology, 100, 143-147.

doi:10.1002/(SICI)1096-8644(199605)100:1<143::AIDAJPA13>3.0.CO;2-0

[30] Peters, C.R. (1982) Electron-optical microscopic study of incipient dental micro damage from experimental seed and bone chrushin. American Journal of Physical Anthropology, 57, 283-301. doi:10.1002/ajpa.1330570306

[31] Fox, C.L. and Perez-Perez, A. (1994) The diet of the Neanderthal child gibraltar through the study of the vestibular striation pattern. Journal of Human Evolution, 24, 2941. doi:10.1006/jhev.1993.1004

[32] Organ, J.M., Teaford, M.F. and Larsen, C.S. (2005) Dietary inferences from dental microwear at mission San Luis de Apalachee. American Journal of Physical Anthropology, 128, 801-811. doi:10.1002/ajpa.20277

[33] Schmidt, C. (2001) Dental microwear evidence for a dietary shift between two non-maize-reliant prehistoric human populations from India. American Journal of Physical Anthropology, 114, 139-145. doi:10.1002/1096-8644(200102)114:2<139::AID-AJPA1 013>3.0.CO;2-9

[34] Walker, A., Hoeck, H.N. and Perez, L. (1978) Micro wear of mammalian teeth as an indicator of diet. Science, 201, 908-910. doi:10.1126/science.684415 